\title{
Phylogeography of Mabuya maculilabris (Reptilia) from São Tomé Island (Gulf of Guinea) inferred from mtDNA sequences
}

\author{
José Jesus ${ }^{\mathrm{a}}$, D. James Harris ${ }^{\mathrm{b}}$, António Brehm ${ }^{\mathrm{a}, *}$ \\ ${ }^{a}$ University of Madeira, Campus of Penteada, 9000-390 Funchal, Portugal \\ ${ }^{\mathrm{b}}$ Centro de Investigação em Biodiversidade e Recursos Genéticos (CIBIO \UP), ICETA, Campus Agrario de Vairão, 4485-661 Vila do Conde, Portugal
}

Received 20 December 2004; revised 30 March 2005

Available online 8 August 2005

\begin{abstract}
The pattern of genetic variation of the lizard Mabuya maculilabris from São Tomé Island (Gulf of Guinea) was investigated using a combination of three mitochondrial DNA gene fragments. Forty-eight haplotypes were recovered among 66 individuals covering the whole island. The genealogy inferred from the most parsimonious network of haplotypes allows us to detect two main and long branches departing from the putative group of oldest haplotypes. The tips of these branches exhibit star-like phylogenies, which may indicate of recently expanded populations, most probably from a small number of founders. A nested clade analysis suggests a complex pattern of past events that gave rise to the extant geographical pattern found in the haplotype distribution: past and allopatric fragmentation, range expansion, restricted gene flow and long-distance dispersal. These results are consistent with the complex geological history of the island where important volcanic activity with extensive lava flows has occurred during several periods. Mismatch-distribution analysis and AMOVA also support these conclusions. Substantial genetic structuring among these lizards was detected as well as high levels of differentiation between the southern edge populations (particularly those from the Rolas Islet) and the remaining ones. However, variation is low relative to the geological age of the island. Our results indicate that patterns of variation observed in reptiles in other oceanic islands are not indicative of those observed in the islands of the Gulf of Guinea.
\end{abstract}

(c) 2005 Elsevier Inc. All rights reserved.

Keywords: Mabuya maculilabris; São Tomé Island; Gulf of Guinea; mtDNA; Phylogeography

\section{Introduction}

The genus Mabuya (sensu Greer, 1977) is the only lizard genus with a circumtropical distribution. More than 100 species are known from Asia, Africa and the Neotropics (Greer et al., 2000). Some species are also very widespread; for example, Mabuya maculilabris has been reported from São Tomé and Príncipe Islands in the Gulf of Guinea (Bocage, 1903; Bocage, 1904-05), from across Central Africa, and on islands in the Indian

\footnotetext{
${ }^{*}$ Corresponding author. Fax: +351291705380.

E-mail address: brehm@uma.pt (A. Brehm).
}

Ocean (e.g., Zanzibar and the Comores). Based on mtDNA sequence data, a recent review of taxa from São Tomé and Príncipe islands showed that populations from Príncipe are well differentiated from those of São Tomé, probably constituting a distinct taxon (Jesus et al., 2005a), and that both are well differentiated from continental M. maculilabris. However, pending taxonomic reform, we continue to refer to the species as "M. maculilabris."

The island of São Tomé is situated in the Gulf of Guinea, $275 \mathrm{~km}$ west of Gabon. This volcanic island is part of an extension of the $1600 \mathrm{~km}$ long "Cameroon Volcanic Line" (Deruelle et al., 1991; Caldeira and Munhá, 2002, Fig. 1) and has never been connected to 


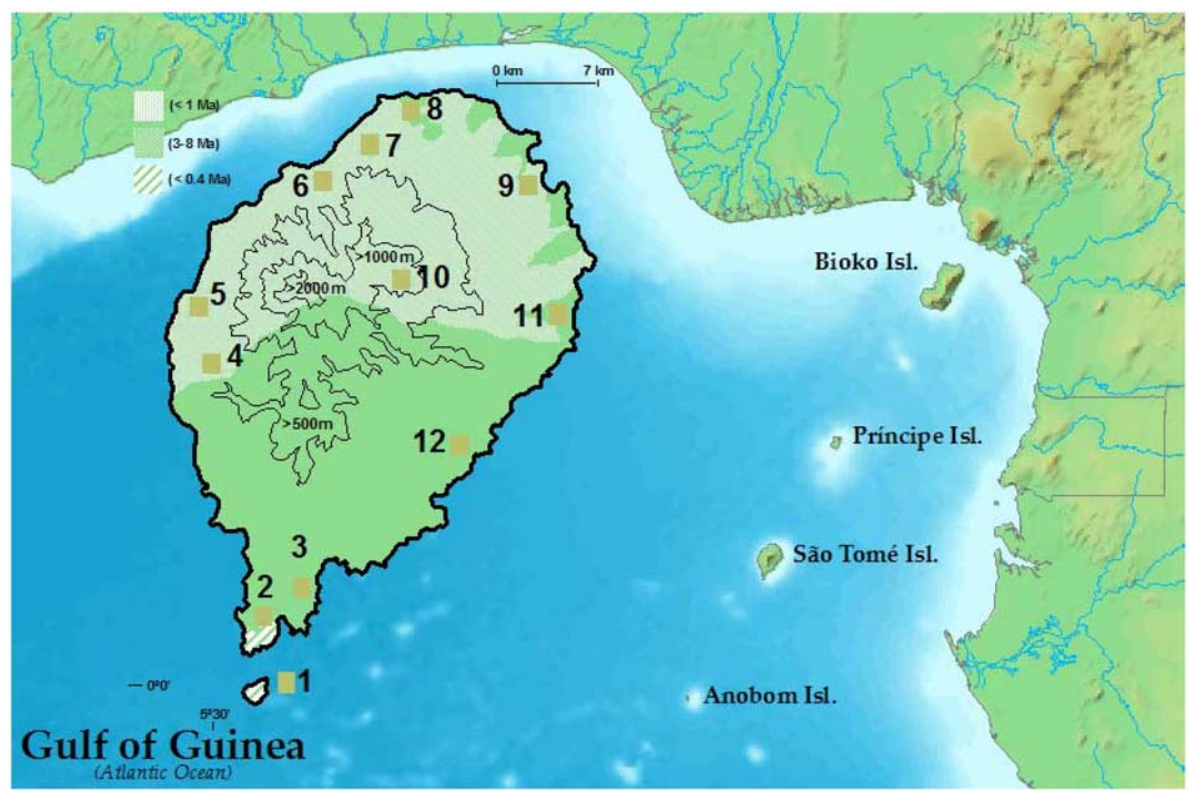

Fig. 1. Sampling sites of Mabuya maculilabris specimens from the island of São Tomé, used in this study. Numbers are as follows: 1 . Rolas Islet, 2. Porto Alegre, 3. Monte Mário, 4. Ponta Furada, 5. Santa Catarina, 6. Neves, 7. Ribeira Funda, 8. Lagoa Azul, 9. São Tomé, 10. São Nicolau, 11. Santana, 12. São João dos Angolares. The map show altitude contours. Shaded areas show the geography of lava flows from different ages (see text).

the mainland or neighbouring islands. São Tomé is made of basaltic lavas lying in Cretaceous sandstones that reach $2024 \mathrm{~m}$ above sea level. The oldest dated volcanic rocks are 15.7 million years (My) old (Deruelle et al., 1991) but most are basaltic lavas less than 1 My old (Munhá et al., 2002); well preserved recent $(<0.4 \mathrm{My}$; Munhá et al., 2002) pyroclastic cones are frequent in the northeast as well as in the south extreme of the island (Caldeira and Munhá, 2002 , see their Fig. 1). The south and southeast part of the island exposes an older volcanic period (3-8 My, Caldeira and Munhá, 2002). The southern edge of the island as well as the Rolas Islet is mainly composed of pyroclastic and lava cones less than $0.4 \mathrm{My}$. The sea depth between the main island of São Tomé and the Rolas islet is less than $100 \mathrm{~m}$, and it is supposed that both complexes were connected by land mass recently during the last glaciation period. In other volcanic islands with similar geologically-complex histories, such as Tenerife in the Canary Islands, phylogeographic analyses have revealed extensive genetic variability within reptile species, coinciding with geologically distinct regions (Gubitz et al., 2000, 2005; Pestano and Brown, 1999; Thorpe et al., 1994). However other than Hemidactylus geckos (Jesus et al., 2005b) there are no phylogeographic studies on reptiles from the islands of the Gulf of Guinea. We use phylogeographic methods to examine geographic structuring of extant lineages of M. maculilabris, and to clarify its evolutionary history relative to the known geology of the island. We can then compare this to other reptile species from volcanic islands, especially the Canary Islands and Cape Verde Islands.

\section{Materials and methods}

\subsection{Samples and sequencing of $D N A$}

Sixty-six specimens of Mabuya maculilabris were collected from 12 localities in São Tomé Island (Fig. 1). All individuals used in this study are deposited in the reptile collection of the University of Madeira under voucher numbers identified by locality-haplotype numbers, i.e., M. maculilabris 6-1. Genomic DNA from each individual was extracted by phenol-chloroform standard protocols. PCR primers used in both amplification and sequencing were $12 \mathrm{Sa}$ and $12 \mathrm{Sb}, 16 \mathrm{SL}$ and $16 \mathrm{SH}$ and cytb1 and cytb3 from Kocher et al. (1989), Simon et al. (1991) and Palumbi et al. (1991) respectively, following conditions given in Harris et al. (1998). PCR fragments were sequenced in an ABI 310 sequencer. Sequences were aligned using Clustal X (Thompson et al., 1994), and minor adjustments were made by eye. Alignment was facile as only single base insertions or deletions were required. To test for conflicting phylogenetic signals among different gene regions of the mtDNA genome we used a partition-homogeneity test, which revealed no significant incongruence among the three regions, thus validating their use combined as a single haplotype. Sequences from three individuals have been previously published (Jesus et al., 2005a).

All 66 individuals were amplified for all three gene fragments, and these sequences were merged in individual haplotypes. Variable positions of the entire sequences excluding indels are shown in Table 1. Complete fragments from each gene are deposited in GenBank under Accession Nos. AY997701-AY997770. 
Table 1

Variable sites of the 12S rRNA, cytochrome $b$ and 16S rRNA gene sequences, in 66 individuals of Mabuya maculilabris (indels were disregarded)

\begin{tabular}{|c|c|c|c|c|c|c|c|c|c|c|c|c|c|c|c|c|c|c|}
\hline & & & & & & & & & & & & & 12222224 & 4444455556 & 6667777777 & 8888888999 & $\begin{array}{r}111 \\
9999999001\end{array}$ & $\begin{array}{l}111111111 \\
122222334 \\
844455262\end{array}$ \\
\hline Hpl & 1 & 2 & 3 & 4 & 5 & 6 & 7 & 8 & 9 & 10 & 11 & 12 & $\begin{array}{l}1782356671 \\
1609094650\end{array}$ & $\begin{array}{l}3457700690 \\
8923603092\end{array}$ & $\begin{array}{l}2560027789 \\
9051413614\end{array}$ & $\begin{array}{l}1133359001 \\
3802944054\end{array}$ & $\begin{array}{l}2488999243 \\
4736013601\end{array}$ & $\begin{array}{l}844455262 \\
825869224\end{array}$ \\
\hline $\mathrm{H} 1$ & & & & & & 1 & & & & & & 1 & CGAGGTCCAC & CCAACCGCTT & GTAGGATGCC & ACCCCCTATC & CGCCCTGCCG & ACTGGCGCC \\
\hline $\mathrm{H} 2$ & & & & & & & & & & & 1 & & т.А. $\ldots$ & $\ldots \ldots$ А. & $\ldots$ А $\ldots \ldots$ & .т..... & .тт..... & $\ldots \ldots \ldots$ \\
\hline H3 & & & & & & & & & & & 2 & & т.А..... & $\ldots \ldots \ldots$ & $\ldots$ A. $\ldots \ldots$ & .т...... & . & G... \\
\hline H4 & & & & & & & & & & & 1 & & т..А.... & ..G..... & $\ldots$ АA. $\ldots \ldots$ & .т...... & .тт..... & $\ldots \ldots \ldots$ \\
\hline H5 & & & & & & & & & & & 1 & & т.А..... & $\ldots \ldots \ldots c$ & $\ldots$ А. $\ldots \ldots$ & $\ldots \ldots \ldots \ldots$ & \#т...т. & $\ldots \ldots \ldots$ \\
\hline $\mathrm{H} 6$ & & & 1 & & & & & & & & 1 & & T. . А.... & $\ldots \ldots \ldots \ldots$ & $\ldots A \ldots \ldots$ & .т...... & .тт..... & $\ldots \ldots \ldots$ \\
\hline H7 & & & & & & & & & & & 1 & & т.А. & .G...... & $\ldots$ А. & .т....G. & .тт..... & $\ldots \ldots \ldots$ \\
\hline H8 & & & & & & & & & & & 1 & & т.А..... & $\ldots \ldots \ldots$ & .A.G... & .т...... & ... TGт. & $\ldots \ldots \ldots$ \\
\hline H9 & & & & & 2 & & & & & & & & ........... & .......... & ......... & ........... & .... тит... & $\ldots \ldots \ldots$ \\
\hline H1O & & & & & 3 & & & & & & & & $\ldots \ldots \ldots \ldots$ & $\ldots \ldots \ldots \ldots$ & ....G.... & $\ldots \ldots \ldots$ & $\ldots \ldots \ldots$ & $\ldots \ldots \ldots$ \\
\hline H11 & & & & & & & & & & & 1 & & \#А.т. & $\ldots \ldots \ldots c$ & $\ldots$.А. $\ldots$ & G........ & .т.тGт... & $\ldots \ldots \ldots$ \\
\hline H12 & & & & & 1 & & & & & & & & $\ldots$ A. & $\ldots \ldots \ldots$ & $\ldots$ А. $\ldots$ & .т. & A. $\ldots \ldots \ldots$ & $\ldots$ A. \\
\hline H13 & & & & & & & 1 & & & & & & $\ldots$ A...... & & $\ldots \ldots \ldots$ & .......... & & \\
\hline H14 & & & 1 & & & & & & & & & & ...А. & T.G.TT..CC & A. .A..CA. & ....... & .т...... & $\ldots \ldots \ldots$ \\
\hline H15 & & 1 & & & & & & & & & & & т..А.... & $\ldots \ldots \ldots c$ & $\ldots$ A. $\ldots \ldots$ & .т..... & .тт..... & $\ldots \ldots \ldots$ \\
\hline H16 & & 1 & & & & & & & & & & & т..А.... & T.G.TT..CC & А....CA. & …… & .т...... & …А. \\
\hline H17 & & & & & & & & & & & 1 & 1 & т.А..... & $\ldots \ldots \ldots c$ & $\ldots$ А. $\ldots \ldots$ & $\ldots \ldots \ldots$ & .т...... & $\ldots \ldots$ \\
\hline H18 & 2 & & & & & & & & & & & & \#А.т. & T.G.TT..CC & A. .A..CA. & ....... & . . т.... & ....... \\
\hline H19 & & 1 & & & & & & & & & & & $\ldots$ A. & T.G.TT..CC & A. .A. CA. & ........ & .т...... & $\ldots \ldots \ldots$ \\
\hline $\mathrm{H} 2 \mathrm{O}$ & & & & & & 1 & 1 & & & & & & $\ldots \ldots \ldots$ & $\ldots \ldots \ldots \ldots$ & $\ldots \ldots \ldots$ & $\ldots \ldots \ldots$ & $\ldots \ldots \ldots$ & $\ldots$ А. $\ldots$ \\
\hline H21 & & & & & & & 2 & & & & & & $\ldots$ A. . . . & $\ldots \ldots \ldots \ldots$ & $\ldots \ldots \ldots \ldots$ & ......... & ... TGT . & $\ldots \ldots \ldots$ \\
\hline H22 & & & & & & 1 & & & & & & & т..А.... & $\ldots \ldots \ldots \ldots$ & .A.G.... & .т...... & .тт...... & $\ldots$. \\
\hline H23 & 2 & & & & & & & & & & & & …А. & T.G.TT.TCC & A....CA. & ......... & . т....... & ........ \\
\hline $\mathrm{H} 24$ & 2 & & & & & & & & & & & & \#А. т. & T.G.TT..CC & A. .A. . CAT. & ….... & . т....... & …A. \\
\hline H25 & 1 & & & & & & & & & & & & \#А. & T.G.TT..CC & A.GA..CA.. & $\ldots \ldots \ldots c$ & .т. & ....... \\
\hline H26 & & & & & & 1 & & & & & & & $\ldots \ldots \ldots$ & $\ldots \ldots \ldots \ldots$ & $\ldots \ldots \ldots$ & $\ldots \ldots \ldots$ & $\ldots \ldots \ldots$ & …․ \\
\hline H27 & & & & & 1 & & & & & & & & $\ldots \ldots \ldots \ldots$ & $\ldots \ldots \ldots$ & .G..G.... & $\ldots \ldots \ldots$ & $\ldots \ldots \ldots$ & $\ldots \ldots \ldots$ \\
\hline H28 & & & & & & & & & & & 1 & & T..А..... & $\ldots \ldots \ldots \ldots$ & .С.А.... & . тт...... & . . TTTGT... & .с. .т. \\
\hline H29 & 1 & & & & & & & & & & & & \#А..т. & T.G.TT..CC & A..A..CA.. & ‥ттас. & 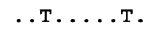 & ․А․ \\
\hline H3O & & & & & & & & & & 1 & & & T..A...G. & $\ldots \ldots \ldots$ & .А.... & $\ldots \ldots \ldots$ & А.тTTGT... & … \\
\hline H31 & & & & & & & & & & 1 & & & T........ & ......... & .C.A.W. & . тт..... & . .TTTGT... & ...... \\
\hline H32 & & & & & & 1 & & & & & & & т.А..... & $\ldots \ldots \ldots \ldots$ & $\ldots$ A. $\ldots \ldots$ & .т.т.... & .тт..... & $\ldots \ldots \ldots$ \\
\hline H33 & & & & 1 & & & & & & & & & .G.A.T. & T.G.TT..CC & A..A..CA. & .т...с. & .т. & \\
\hline H34 & & & & & & 1 & & & & & & & $\ldots \ldots \ldots$ & ......... & $\ldots \ldots \ldots$ & $\ldots \ldots \ldots$ & . .т..... & $\ldots \ldots \ldots$ \\
\hline H35 & & & & & & 1 & & & & & & & т..А.... & $\ldots \ldots \ldots \ldots$ & $\ldots$ А. $\ldots \ldots$ & .тет.... & . .т..... & $\ldots \ldots \ldots$ \\
\hline H36 & & & 1 & 1 & & & & & & & & & \#а..т. & T.G.TT..CC & A..A..CA. & ........ & А.т...... & \\
\hline H37 & & 1 & & & & & & & & & & & т..А..... & $\ldots \ldots \ldots$ cc & $\ldots$ А. $\ldots \ldots$ & .т...... & . .тTтGт... & $\ldots$ \\
\hline H38 & & 1 & & & & & & & & & & & \#А.т. & T.G.TT..CC & А....СA. & …татс.с. & .т..... & \\
\hline H39 & & & & & & & & & & & & 1 & … А. & $\ldots \ldots \ldots c$ & $\ldots$ А. $\ldots \ldots$ & $\ldots \ldots \ldots \ldots$ & .?т.TGT... & $\ldots$ \\
\hline H40 & & & & & & & & & & & 1 & & т..А..... & ......... & $\ldots$. & .т.... & .т.тGт... & $\ldots \ldots \ldots$ \\
\hline H41 & & & & 1 & & & & & & & & & .т..с... & $\ldots \ldots \ldots \ldots$ & ....G.... & $\ldots \ldots \ldots$ & ...ттт. & $\ldots \ldots \ldots$ \\
\hline H42 & & & & & & & & & 1 & & & & т..А..... & $\ldots \ldots \ldots \ldots$ & $\ldots$ A.G... & .тет.... & .T.TGT..A & $\ldots \ldots \ldots$ \\
\hline $\mathrm{H} 43$ & & & & & & & & & 1 & & & & T..A...... & ........... & $\ldots$........ & .т.т..... & . TT.....A & $\ldots \ldots \ldots$ \\
\hline H44 & & & & & & & & 1 & & & & & Т..А... & & $\ldots$.А. & .т...... & .тт..... & . т. \\
\hline H45 & & & & & & & & & & & & 1 & \#А..т. & $\ldots \ldots \ldots c$ & $\ldots$ А. $\ldots \ldots$ & $\ldots \ldots \ldots \ldots$ & .АT. $\ldots \ldots$ & $\ldots \ldots \ldots$ \\
\hline H46 & 1 & & & & & & & & & & & & ..... & T.G.TT..CC & A..A..C... & ...т.... & . т....... & ....... \\
\hline H47 & 1 & & & & & & & & & & & & \#А.т. & T.G.TT..CC & A..A.GCA. . & т.....с. & .т...... & …А. \\
\hline H48 & 1 & & & & & & & & & & & & \#А.Т. & TTG.TT..CC & А..А.СА. & $\ldots \ldots \ldots$ с & .т...... & …А \\
\hline
\end{tabular}

Following the haplotype is the number of individuals bearing the same sequence. Digits at the top of the Table indicate nucleotide positions relative to the beginning of sequences deposited in GenBank. Dots represent identical bases to the first haplotype. Hpl is the haplotype number, numbers 1-12 are the sites of collection (see Fig. 1).

\subsection{Data analysis}

Analysis of the phylogeographic structure of Mabuya maculilabris mtDNA haplotypes was performed using nested clade analysis (NCA). A statistical parsimony algorithm (Templeton et al., 1992) with nesting rules extended in Crandall (1996) was performed in TCS (Clement et al., 2000). The estimated maximum number of differences among haplotypes as a result of single substitutions with a $95 \%$ confidence level allowed all the haplotypes to be joined in a single network. The program TCS was also used to reconstruct an unrooted haplotype genealogy and to estimate the most ancestral haplotype. Ambiguities of the nesting design were resolved following Crandall and Templeton (1993) and Crandall et al. (1994). The nesting design was constructed following Templeton et al. (1987). Associations between this nesting topology and geographical dis- tances among populations were tested with GEODIS (Posada et al., 2000). This program estimates two distances: clade distance $\left(D_{\mathrm{c}}\right)$ as a measure of the geographical range of clades at each hierarchical level, and nested clade distance $\left(D_{\mathrm{n}}\right)$, which measures the geographic position of a clade relative to sister clades. Both distances are used to calculate the average interior (ancestral) clade distance minus the average tip clade distances $(I-T)_{\mathrm{c}}$ and $(I-T)_{\mathrm{n}}$. The hypothesis that dispersion distances of clades are not significantly greater or less than expected at random was tested by comparing $D_{\mathrm{c}}$ and $D_{\mathrm{n}}$ values with those obtained after 10,000 random permutations of clades against sampling locations. The statistics were then used to infer biological explanations of the results under a null hypothesis of no association between haplotype topology and geographical distribution. The biological interpretations of the results follow the inference key of Templeton (2004). 
An analysis of molecular variance (AMOVA, Excoffier et al., 1992) was performed based on Euclidean distances between haplotypes using Arlequin (Schneider et al., 2000). The total genetic variation was partitioned among three groups of populations: the ones from more recent lava (populations 1-2), those from intermediateaged lava flows (5-10) and the ones from older lava flows (3-4, 11-12) (Fig. 1). Another AMOVA was performed based on a geographical clustering of populations: Rolas Isl. (1), southern edge of S. Tomé Isl. (2-3), East coast (912) and West coast (4-8). These were chosen to try to assess whether geological history or current geography better explains genetic variability within Mabuya maculilabris.

To test for demographic signatures of population expansions within the island of São Tomé, we used the mismatch-distribution analysis (Rogers and Harpending, 1992) and compared the observed distribution with the expected under the assumption of an expansion model by calculating the raggedness index (Rogers and Harpending, 1992). We also calculated Fu's $F_{\mathrm{s}}(\mathrm{Fu}$, 1997) as a test of neutrality using Arlequin v.2.000 (Schneider et al., 2000). Under an infinite-site model, large values of $F_{\mathrm{s}}$ provide evidence for population expansion.

\section{Results and discussion}

A total of 48 haplotypes were identified in the 66 individuals included in this study (Table 1). Most of these haplotypes were found only in single specimens but haplotype six was found in eight specimens from three different localities.

All haplotypes can be connected by less than nine mutational steps and following Templeton et al. (1992) have a probability of $>95 \%$ of being parsimoniously connected. Fig. 2 shows the maximum parsimony network of 48 haplotypes and the nested clade design. Haplotype $6(\mathrm{H} 6)$ is considered the most probable ancestral haplotype. Homogeneity testing revealed significant non-random association of clades and sampling locations, indicating that a phylogeographic structure exists especially at higher hierarchical clade levels. Table 2 presents the interpretations of the nested clade analysis of geographical distances according to the latest key of Templeton (2004). A significant geographical association is detected under our nested design in four clades at different hierarchical levels and at the total-cladogram level: 2-1 (due to interior clade 1-1), 2-16 (due to a low $D_{\text {c }}$ of clade 1-43), 3-4 (due to a low $D_{\text {c }}$ of clade 2-11), clade 4-1 (which presented statistically significant $D_{\mathrm{c}}$ and $D_{\mathrm{n}}$ values at clades 3-1 and 3-2) and finally the entire cladogram (with all nested clades presenting either statistically small or large values for $D_{\mathrm{c}}$ and $D_{\mathrm{n}}$ ). Except in two instances the network is fully resolved (Fig. 2). The geographical distance analysis shows significant differences at different clade levels (either clade- $D_{\mathrm{c}}$ or nested clade $D_{\mathrm{n}}$ distances), and with one exception, allows drawing of demographic inferences according to the key of Templeton (2004) (Table 2).

The entire cladogram points to restricted gene flow or dispersal but with some long-distance dispersal (see Table 2). Mabuya maculilabris in São Tomé is characterized by a closely related group of haplotypes (clades 3-1 and 3-2), which are spread over almost the entire island (except Rolas) independent of lava ages. From the statistical-parsimony network, two long and well separated branches emerge clearly from H17, which is linked to the putative oldest haplotype by only two mutational steps. One of these branches is mainly concentrated in the southern edge of S. Tomé; eight haplotypes from Rolas Islet represent the extreme tip of this branch, and none of these are found elsewhere. The characteristic "starlike" topology of haplotypes from Rolas indicates a demographic expansion (Slatkin and Hudson, 1991). The expansion is probably a recent dispersal from the closest haplotypes in the south of the nearby main island (populations 2 and 3). The NCA indicates that the haplotype distribution within clades 3-4 is significantly associated with geography, probably as the result of past fragmentation. Haplotypes from Rolas Islet were not found in the main island but the most closely related haplotypes are those from populations 2 and 3. If one assumes a molecular clock of $\approx 1.96 \%$ per million years (My) calibrated from Mabuya of Cape Verde islands (Carranza et al., 2001) and a sequence divergence between Rolas and both populations from the southern edge of São Tomé of $0.28 \%$, the separation of the former population took place at least $\approx 150,000$ years ago. This age agrees well with the geological data, which indicates important volcanic activity in the area around 0.4 $0.5 \mathrm{My}$ (Munhá, pers. comm.). The lack of shared haplotypes between Rolas and the southern coast of São Tomé is also evidence that gene flow among the two regions is low or nonexistent. The most ancestral haplotype (H6) of São Tomé, although not detected in Rolas, is quite widespread along the southeast part of the island. The data suggests that this region was probably the first to be colonized by $M$. maculilabris. From this region the populations spread in two distinct lineages: a widely distributed one ending in the islet of Rolas and another more concentrated in the central and western part of the island (clades 3-5 to 3-7). Most of the haplotypes from São Tomé are private haplotypes; only four are shared by more than one population, indicating that the whole population may have experienced a past fragmentation history. Although lack of sampling density could also explain this result, Mabuya are large, mobile animals, and our sampled populations are spread throughout the island, making this explanation less likely. The second-longest branch in the topology con- 


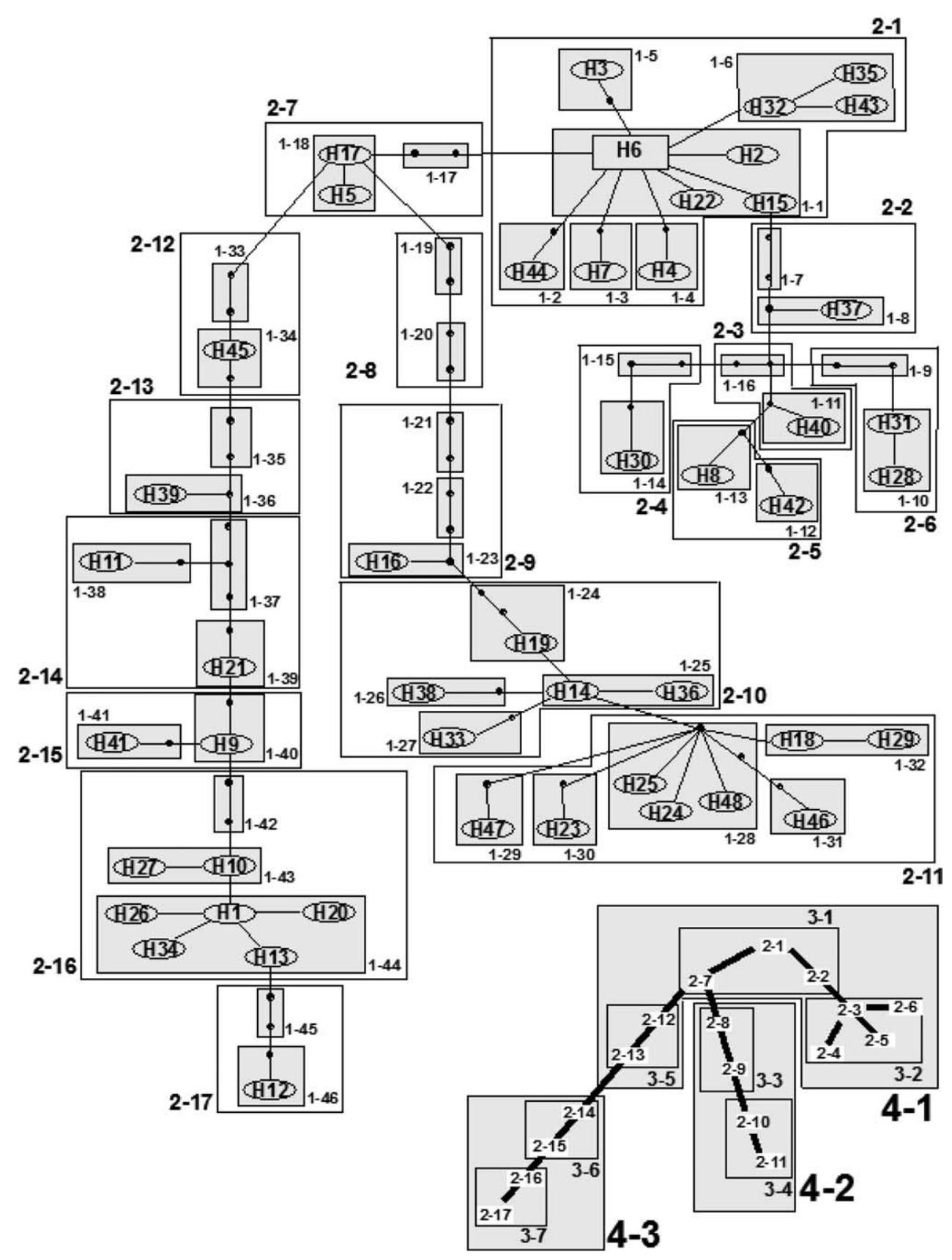

Fig. 2. Maximum parsimony network of Mabuya maculilabris haplotypes (labelled as in Table 1) and nested clade design. Missing haplotypes are indicated by black circles. Haplotype 6 has the highest outgroup probability. The clades are identified using the two-number system where the first refers to the nesting hierarchy and the second is an arbitrary individual clade identifier. Each line represents a single mutational step between two haplotypes. Oval shapes are not proportional to haplotype frequency. Two ambiguous connections linking H32 to the unknown haplotype from clade 1-5, and H21-H13 were removed following the procedures outlined by Templeton and Sing (1993).

tains most of its diversity in the northwest coast of the island. The whole clade 2-16 has a sequence divergence to the ancestral type of $0.51 \%$, which estimates a divergence time of approximately 260,000 years. Although the haplotype distribution and distances are significantly associated, a strict interpretation of the inference key of Templeton is inconclusive. Nevertheless, the estimated coalescence date of clades 4-2 and 2-1, which includes the putative ancestral haplotype as well as derived ones (some also existing in the southern edge of the island), puts the origin of all extant lineages around 800,000 ya. This date is surprising given the age of the island and the high genetic differentiation between populations from São Tomé and Principe, its presumed sister taxon (Jesus et al., 2005a). Although error rates of molecular clocks are substantial, especially when comparing closely related populations, this age is very different from the $\approx 5 \mathrm{My}$ separating populations from São Tomé and 
Table 2

Interpretation of the results of Fig. 2 using the key of inference of Templeton (2004)

\begin{tabular}{lll}
\hline Clade & Chain of inference & Demographic event inferred \\
\hline $2-1$ & $1-2-11-12-13-Y E S$ & Past fragmentation followed by range expansion \\
$2-16^{*}$ & $1-19-20-2-11-17-N O$ & Inconclusive outcome \\
$3-4^{* *}$ & $1-19-20-2-3-4-9-N O$ & Allopatric fragmentation \\
$4-1$ & $1-2-3-5-6-7-8-N O$ & Unable to discriminate between isolation by distance and long distance movements \\
TC & $1-2-3-5-6-7-Y E S$ & Restricted gene flow/dispersal but with some long distance dispersal \\
\hline
\end{tabular}

TC, total cladogram.

* Permutational $x^{2}$ statistic $=11.0(P<.005)$.

** $x^{2}$ statistic $=16.0(P<.0001)$.

*** $x^{2}$ statistic $=33.79(P<.005)$.

Príncipe using the same rate estimate (Jesus et al., 2005a). It thus highlights the problems of using island ages to calibrate molecular clocks - coalescent dates for haplotypes within islands are often substantially less than the age of the islands, as seen here and in the case of Lacerta dugesii in Madeira (Brehm et al., 2003).

The AMOVA analysis further confirms that São Tomé M. maculilabris populations are structured. The clustering of populations according to geography (three groups, southern edge of São Tomé, east and west coasts) yields an $F_{\mathrm{ST}}$ value of 0.54 with $25 \%$ of the variation attributed to differences among the three groups and $28 \%$ attributed to differences among populations within groups $(P<.0001)$. The clustering of populations according to ages of lava flows gave values of $11 \%$ of variation attributed to differences among groups and $40 \%$ among populations within groups $\left(F_{\mathrm{ST}}\right.$ of 0.52). Thus the geographic separation better explained genetic variation than separation based on age of lava. Pairwise mismatch analysis (Fig. 3) clearly shows a bimodal distribution of pairwise differences, which is expected when populations are geographically subdivided (Marjoram and Donnelly, 1994). Such clear bimodal data (with peaks clearly separated) further suggests that the initial population size was high and coupled with a probably low migration rate. This is also consistent with the geological history of São Tomé with constant lava flows through complex chains of valleys around the volcano (Caldeira and Munhá, 2002). Further evidence that M. maculilabris in São Tomé is experiencing a population expansion comes from the large value of $F_{\mathrm{S}}$ for the whole population $(\mathrm{Fu}, 1997)$ as well as the parameters of mismatch distribution obtained (Fig. 3).

In conclusion, all analyses show a degree of geographic population substructuring within Mabuya maculilabris consistent with the known geology of the island. In this respect the results are similar to those obtained from reptiles from other geologically-complex islands such as Tenerife. However the level of variation within

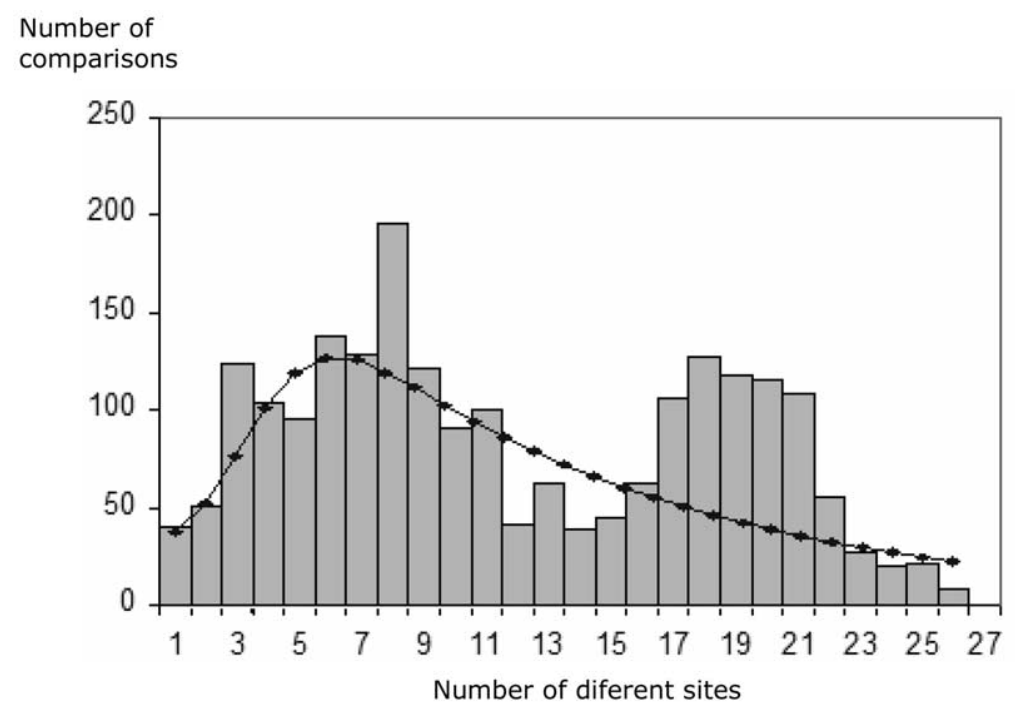

Fig. 3. Mismatch-distribution analysis of Mabuya maculilabris mtDNA haplotype sequences from São Tomé Island. A simulated Poisson distribution is indicated by a dotted line. The group fits a wave characteristic of an episode involving population growth, although the bimodal shape clearly indicates that population fragmentation is also involved. Fu's $F_{\mathrm{s}}$ test of selective neutrality yielded a value of $F_{\mathrm{s}}=-24.457$, a $P_{\mathrm{F}}<0.0001$ (probability that simulated $F_{\mathrm{s}}$ under 1000 bootstraps is less or equal to the observed $\left.F_{\mathrm{s}}\right), \tau=3.841, \theta_{0}=11.012$ and $\theta_{1}=44.297$, and the Harpending (1994) raggedness index, which measures the "smoothness" of the mismatch distribution is $=0.00462$. 
M. maculilabris is low compared to reptiles from Tenerife, which is surprising given that São Tomé is geologically older (15 My vs $11 \mathrm{My}$ for Tenerife). Variation is also very low given the age of the island within Lacerta dugesii from Madeira (Brehm et al., 2003). However this latter result can be explained by the greater degree of geographical isolation of Madeira. Our results indicate that more studies are needed from more volcanic island archipelagos before comparative phylogeographic conclusions can be drawn.

\section{Acknowledgments}

This work was financed under contract POCTI/ 41906/BSE/2001 from Fundação para a Ciência e Tecnologia (Lisbon, Portugal). The authors are indebted to the Government of São Tomé e Príncipe for permissions to perform field work and AMI-Assistência Médica Internacional for local support. Thanks to the handling editor and two anonymous reviewers for their constructive comments on an earlier draft of this manuscript.

\section{References}

Bocage, J.V.B., 1903. Contribution à la faune des quatre îles du Golfe de Guinée. Jornal de Sciencias Mathematicas Physicas e Naturais $2^{\mathrm{a}}$ Série VII (25), 25-59.

Bocage, J.V.B., 1904-1905. Contribution à la faune des quatre îles du Golfe de Guinée. Jornal de Sciencias Mathematicas Physicas e Naturais, 2a Série VII (26), 65-96.

Brehm, A., Jesus, J., Spínola, H., Alves, C., Vicente, L., Harris, D.J., 2003. Phylogeography of the Madeiran endemic lizard Lacerta dugesii inferred from mtDNA sequences. Mol. Phylogenet. Evol. 26, 222-230.

Caldeira, R., Munhá, J.M., 2002. Petrology of ultramafic nodules from São Tomé Island, Cameroon Volcanic Line (oceanic sector). J. Afr. Earth Sci. 34, 231-246.

Carranza, S., Arnold, E.N., Mateo, J.A., López-Jurad, L.F., 2001. Parallel gigantism and complex colonization patterns in the Cape Verde scincid lizards Mabuya and Macroscincus (Reptilia: Scincidae) revealed by mitochondrial DNA sequences. Proc. R. Soc. Lond. B $268,1595-1603$.

Clement, M., Posada, D., Crandall, K.A., 2000. TCS: a computer program to estimate gene genealogies. Mol. Ecol. 9, 1657-1659.

Crandall, K.A., 1996. Multiple interspecies transmissions of human and simian T-cell leukemia/lymphoma virus Type I sequences. Mol. Biol. Evol. 13, 115-131.

Crandall, K.A., Templeton, A.R., 1993. Empirical tests of some predictions from coalescent theory with applications to intraspecific phylogeny reconstruction. Genetics 134, 959-969.

Crandall, K.A., Templeton, A.R., Sing, C.F., 1994. Intraspecific phylogenetics, problems and solutions. In: Scotland, R.W.L., Siebert, D.J., Williams, D.M. (Eds.), Phylogeny reconstruction. Oxford University Press, Oxford, pp. 81-99.

Deruelle, B., Moreau, C., Nkoumbou, C., Kambou, R., Lissom, J., Njongfang, E., Ghogomu, R.T., Nono, A., 1991. The Cameroon Line: a review. In: Kampunzu, A.B., Lubala, R.T. (Eds.), Magmatism in extensional structural settings. Springer Verlag, Berlin, Germany, pp. 274-327.

Excoffier, L., Smouse, P., Quattro, J.M., 1992. Analysis of molecular variance inferred from metric distances among DNA haplotypes:
Application to human mitochondrial DNA restriction data. Genetics 131, 479-491.

Fu, Y.X., 1997. Statistical tests of neutrality of mutations against population growth, hitchhiking and background selection. Genetics 147, 915-925.

Greer, A.E., 1977. The systematics and evolutionary relationships of the scincid lizard genus Lygosoma. J. Nat. Hist. 11, 515-540.

Greer, A.E., Arnold, C., Arnold, E.N., 2000. The systematic significance of the number of presacral vertebrae in the scincid lizard genus Mabuya. Amphibia-Reptilia 21, 121-126.

Gubitz, T., Thorpe, R.S., Malhotra, A., 2000. Phylogeography and natural selection in the Tenerife gecko Tarentola delalandii: testing historical and adapting hypothesis. Mol. Ecol. 9, 1213-1221.

Gubitz, T., Thorpe, R.S., Malhotra, A., 2005. The dynamics of genetic and morphological variation on volcanic islands. Proc. R. Soc. Lond. B. 272, 751-757.

Harpending, R.C., 1994. Signature of ancient population growth in a low resolution mitochondrial DNA mismatch distribution. Hum. Biol. 66, 591-600.

Harris, D.J., Arnold, E., Thomas, R., 1998. Relationships of lacertid lizards (Reptilia: Lacertidae) estimated from mitochondrial DNA sequences and morphology. Proc. R. Soc. Lond. B. 265, 19391948.

Jesus, J., Brehm, A., Harris, D.J., 2005a. Relationships of scincid lizards (Mabuya spp.) from the islands of the Gulf of Guinea based on mtDNA sequence data. Amphibia-Reptilia (in press).

Jesus, J., Brehm, A., Harris, D.J., 2005b. Phylogenetic relationships of Hemidactylus geckos from the Gulf of Guinea islands: patterns of natural colonizations and anthropogenic introductions estimated from mitochondrial and nuclear DNA sequences. Mol. Phylogenet. Evol. 34, 480-485.

Kocher, T.D., Thomas, W.K., Meyer, A., Edwards, S.V., Pääbo, S., Villablanca, F.X., Wilson, A.C., 1989. Dynamics of mitochondrial DNA evolution in animals: amplification and sequencing with conserved primers. Proc. Natl. Acad. Sci. USA 86, 6196-6200.

Marjoram, P., Donnelly, P.J., 1994. Pairwise comparisons of mitochondrial DNA sequences in subdivided populations and implications for early human evolution. Genetics 136, 673-683.

Munhá, J., Afonso, R., Caldeira, R., Mata, J., 2002. Estudo geológico preliminar da região nordeste da Ilha de $\mathrm{S}$ Tomé (Folha $\mathrm{n}^{\circ} 2$, Ana Chaves). Garcia de Horta (Lisboa) 18, 1-8.

Palumbi, S. R., Martin, A., Romano, S., McMillan, W. O., Stice, L., Grabowski, G. 1991. The Simple Fool's Guide to PCR. Kewalo Marine Laboratory and Univ. of Hawaii.

Pestano, J., Brown, R.P., 1999. Geographical structuring of mtDNA in Chalcides sexlineatus within the island of Gran Canaria. Proc. R. Soc. Lond. B. 266, 815-823.

Posada, D., Crandall, K.A., Templeton, A.R., 2000. GeoDis: a program for the cladistic nested analysis of the geographical distribution of genetic haplotypes. Mol. Ecol. 9, 487-488.

Rogers, A.R., Harpending, I.I., 1992. Population growth makes waves in the distribution of pairwise genetic differences. Mol. Biol. Evol. 9, 552-569.

Schneider, S., Kueffer, J.-M., Roessli, D., Excoffier, L., 2000. Arlequin: a software for population genetics data analysis. Version 2.0, Genetics and Biometry Lab, Dept. of Anthropology, University of Geneva.

Simon, C., Franke, A., Martin, A., 1991. The polymerase chain reaction: DNA extraction and amplification. NATO ASI series. In: Hewitt, G.M., Johnston, A.W.B., Young, J.P.W. (Eds.), Molecular techniques in taxonomy. Springer-Verlag, Berlin, Heidelberg, pp. 329-356.

Slatkin, M., Hudson, R.R., 1991. Pairwise comparisons of mitochondrial sequences in stable and exponentially growing populations. Genetics 129, 555-562.

Templeton, A.R., Boerwinkle, E., Sing, C.F., 1987. A cladistic analysis of phenotypic associations with haplotypes inferred from restric- 
tion endonuclease mapping. I. Basic theory and an analysis of alcohol dehydrogenase activity in Drosophila. Genetics 117, 343351.

Templeton, A.R., Crandall, K.A., Sing, C.F., 1992. A cladistic analysis of phenotypic associations with haplotypes inferred from restriction endonuclease mapping and DNA sequence data. III. Cladogram estimation. Genetics 132, 619-633.

Templeton, A.R., 2004. Statistical phylogeography: methods of evaluating and minimizing errors. Mol. Ecol. 13, 789-809.

Templeton, A.R., Sing, C.F., 1993. A cladistic analysis of phenotypic associations with haplotypes inferred from restriction endonuclease mapping. IV. Nested analysis with cladogram uncertainty and recombination. Genetics 134, 659-669.

Thompson, J.D., Higgins, D.G., Gibson, T.J., 1994. CLUSTAL W: improving the sensitivity of progressive multiple sequence alignment through sequence weighting, positions-specific gap penalties and weight matrix choice. Nucleic Acids Res. 22, 4673-4680.

Thorpe, R.S., McGregor, D.P., Cumming, A.M., Jordan, W.C., 1994. DNA evolution and colonization sequence of island lizards in relation to geological history-mtDNA RFLP, cytochrome- $b$, cytochrome-oxidase, $12 \mathrm{~S}$ ribosomal-RNA sequences and nuclear RAPD analysis. Evolution 48, 230-240. 